\author{
KATARZYNA KORPANTY \\ INSTYTUT SZTUKI, POLSKA AKADEMIA NAUK
}

\title{
TEMATY MUZYCZNE W KORESPONDENCJI FRYDERYKA II I JEGO SIOSTRY WILHELMINY, MARGRABINY VON BAYREUTH*
}

\author{
„Tak jak Ty pozostaję wierny muzyce” \\ z listu Fryderyka II do Wilhelminy z 29 XII I75I r.
}

W

dniu 27 VI 1740 r., niecały miesiąc po objęciu tronu pruskiego, Fryderyk II pisał do Woltera:

Od czasu śmierci mojego ojca uważam, że jestem całkowicie oddany mojej ojczyźnie. W duchu tym pracowałem z całych sił, by jak najszybciej podjąć najodpowiedniejsze środki dla dobra publicznego.

Zacząłem od wzmocnienia sił zbrojnych o szesnaście batalionów, pięć szwadronów husarii i jeden szwadron garde du corps. Położyłem podwaliny pod naszą nową Akademię. Pozyskałem Wolffa, Maupertuis i Algarottiego. Czekam na odpowiedź od 's Gravesande’a, Vaucasona i Eulera. Utworzyłem nowy departament handlu i manufaktury, zatrudniam malarzy i rzeźbiarzy $[\ldots]^{\mathrm{T}}$.

* W polskim piśmiennictwie muzykologicznym temat ten nie został dotychczas podjęty. W niniejszym artykule wykorzystano następujące wydania korespondencji: Correspondance de Frédéric avec sa soeur Wilhelmine, margrave de Baireuth, w: Oeuvres de Frédéric le Grand, red. Johann David Erdmann Preuss, t. 27, cz. I, Berlin I856; Friedrich der Grosse und Wilhelmine von Baireuth, t. I-2, red. Gustav Berthold Volz, przekł. niem. Friedrich von Oppeln-Bronikowski, Leipzig 1924, 1926; „... solange wir zu zweit sind." Friedrich der Große und Wilhelmine Markgräfin von Bayreuth in Briefen, red. Friedrich Wilhelm Prinz von Preußen, Kirsten Heckmann-Janz, Sibylle Kretschmer, przekł. niem. Friedrich von Oppeln-Bronikowski, München 2003; Bagatellen aus Berlin. Briefe Friedrichs II. an Wilhelmine von Bayreuth, red. Günter Berger, Julia Wassermann, przekł. niem. Sarah Breitenbach i in., Berlin 2oIr. Większość listów Fryderyka II i Wilhelminy została opublikowana, ale pełne wydanie ich korespondencji czeka na opracowanie. Niniejszy artykuł jest jedynie przyczynkiem do podjętego tematu.

I „J'ai cru que, depuis la perte de mon père, je me devais entièrement à la patrie. Dans cet esprit, j’ai travaillé autant qu'il a été en moi pour prendre les arrangements les plus prompts et les plus convenables 
Fryderyk II, zwany Wielkim, zapisał się w historii jako wybitny strateg polityczny i wojskowy, pod którego rządami Prusy stały się jednym z najpotężniejszych mocarstw w Europie ${ }^{2}$. Był także wielbicielem nauki i sztuki, co potwierdza przytoczony cytat $^{3}$. Szczególną pasją Fryderyka II była literatura ${ }^{4}$. Z największym zainteresowaniem czytał dzieła autorów antycznych oraz pisarzy francuskich XVII i XVIII wieku. Głęboki podziw budziło w nim literackie mistrzostwo Woltera. Jego obfita korespondencja z twórcą Henriady trwała 42 lata i stanowi cenny dokument epoki. Fryderyk sam miał talent pisarski. Chętnie i często sięgał po pióro. Jest on jedynym wybitnym władca, który pozostawił po sobie wielotomowe dzieła zebranes. Imponujący dorobek twórczy Fryderyka obejmuje: publikacje historyczne, filozoficzne, polityczno-militarne, eseje z zakresu pedagogiki i estetyki, utwory poetyckie oraz libretta operowe. Był ponadto znakomitym epistolografem swojej epoki. Jego korespondencja urzędowa i prywatna liczy wiele grubych tomów. Korespondował z takimi wybitnymi osobistościami ówczesnego europejskiego życia intelektualnego i artystycznego, jak np. wspomniany już Wolter, a także Pierre Louis Moreau de Maupertuis, Jean Le Rond d'Alembert, Jean Baptiste d'Argens, Bernard le Bovier de Fontenelle, Charles Rollin, Francesco Algarotti, Charles Etienne Jordan i Willem Jacob 's Gravesande.

W przeciwieństwie do swojego ojca, króla Fryderyka Wilhelma I, który żywił głęboką pogardę dla nauki i pracy umysłowej ${ }^{6}$, Fryderyk II twierdził, że o sile państwa świadczy nie tylko jego potencjał militarny i gospodarczy, ale i poziom życia kulturalnego kraju. Mocno podkreślał, że aktywność monarchy na polu kultury jest równie istotna jak jego sukcesy militarne. W najważniejszym dziele filozoficznym Fryderyka II

au bien public. J'ai d'abord commencé par augmenter les forces de l'État de seize bataillons, de cinq escadrons de hussards, et d'un escadron de gardes du corps. J'ai posé les fondements de notre nouvelle Académie. J'ai fait acquisition de Wolff, de Maupertuis, d'Algarotti. J'attends la réponse de 's Gravesande, de Vaucanson et d'Euler. J'ai établi un nouveau college pour le commerce et les manufactures; j'engage des peintres et des sculpteurs [...]", cyt. z: Correspondance de Frédéric avec Voltaire, w: Oeuvres de Frédéric le Grand, red. Johann David Erdmann Preuss, t. 22, Berlin I853, s. I2-I3. Wszystkie cytaty w przekł. autorki.

2 Postaci Fryderyka II poświęcono w literaturze naukowej wiele uwagi. Z najważniejszych prac biograficznych wymienić należy m.in.: Pierre Gaxotte, Frédéric II, Paris 1938; George Peabody Gooch, Frederick the Great, the Ruler, the Writer, the Man, New York 1947; Władysław Konopczyński, Fryderyk Wielki a Polska, Poznań 1947; Stanisław Salmonowicz, Fryderyk II, Wrocław 1985; Christopher Duffy, Frederick the Great. A Military Life, London 1985, przekł. polski Miłosza Młynarza pt. Fryderyk Wielki. Biografia wojskowa, Oświęcim 20I7; Johannes Kunisch, Friedrich der Grosse. Der König und seine Zeit, München 2004; Friedrich der Grosse in Europa - Geschichte einer wechselvollen Beziehung, red. Bernd Sösemann, Gregor Vogt-Spira, Stuttgart 2012.

3 W liście do Woltera z I6 I I737 r. wyznał, że największą przyjemność sprawia mu zajmowanie się sztuką. List w: Correspondance de Frédéric avec Voltaire, t. 2I, Berlin I853, s. 32.

4 W liście do Woltera z 25 XI 1769 r. Fryderyk II napisał: „kocham literaturę jak opętany”. List w: ibid., t. 23, Berlin I853, s. I44.

5 Wydanie dzieł Fryderyka II, które w 1. I846-57 opublikował Johann David Erdmann Preuss, liczy trzydzieści tomów.

6 Fryderyk Wilhelm I (I688-1740) tolerował wyłącznie rozwój nauk praktycznych, np. medycyny i ekonomii. Nie pochwalał intelektualnych i artystycznych zainteresowań Fryderyka (m.in. zabronił mu uczyć się łaciny), por.: Grzegorz Kucharczyk, Hohenzollernowie, Poznań 2016, s. I42-I43. 


\section{pt. L'Antimachiavel ou Examen du Prince de Machiavel et Réfutation du Prince de} Machiavel, które opublikowane zostało w roku I740, czytamy:

Najpewniejszym dowodem, że mądrze rządzone państwo jest szczęśliwe, zasobne i bogate, są sztuki piękne i nauki, które kwitną w jego sercu7.

Jedną z pierwszych decyzji Fryderyka jako króla było ponowne przyjęcie na Uniwersytet w Halle wygnanego z Prus przez jego ojca filozofa Christiana Wolffa. Ponadto m.in. odnowił berlińską Akademię Nauk. W jej składzie przeważali Francuzi, bowiem Fryderyk II najwyżej cenił osiągnięcia uczonych francuskich ${ }^{8}$ i był miłośnikiem kultury francuskiej. Zamiłowanie to w dzieciństwie zaszczepili mu jego wychowawcy: Marthe de Rocoulles oraz Jacques-Egide Duhan de Jandun. Oboje wspierali literackie i muzyczne zainteresowania Fryderyka. Im też zawdzięczał doskonałą znajomość języka francuskiego, którym przez całe życie posługiwał się biegle w mowie i piśmie ${ }^{\mathrm{IO}}$.

Jak powszechnie wiadomo, Fryderyk II był ambitnym muzykiem-amatorem ${ }^{\text {II }}$. Dwie siostry Fryderyka, Fryderyka Zofia Wilhelmina ${ }^{\mathrm{I} 2}$ (1709-58) oraz Anna

7 Fryderyk II, L'Antimachiavel, rozdz. XXI, w: Oeuvres de Frédéric le Grand, t. I, Berlin I846, s. 270: „La marque la plus sûre d'un pays qui, sous un gouvernement sage, est heureux, abondant et riche, c'est lorsque les beaux-arts et les sciences naissent en son sein". Pełny wyraz swoim poglądom na temat roli sztuki w życiu człowieka dał trzydzieści dwa lata później, w roku 1772, w eseju pt. Discours de l'utilité des sciences et des arts dans un état. Ponadto m.in. w listach do grafa von Schaumbourg-Lippe wielokrotnie pisał, że sztuka jest ważna i niezbędna w życiu człowieka, por.: Correspondance de Frédéric avec le comte de Schaumbourg-Lippe, w: Oeuvres de Frédéric le Grand, t. I6, Berlin I850 s. 205-206, 207-208.

8 Do nielicznych uczonych niemieckich, których Fryderyk uważał za wybitnych, należeli Gottfried Wilhelm Leibniz i Christian Wolff.

9 Marthe de Rocoulles i Jacques-Egide Duhan de Jandun byli potomkami hugenockich uchodźców. Warto przypomnieć, że w Berlinie bardzo liczna była kolonia francuska, która odgrywała istotną rolę w rozwoju tamtejszej kultury. Prusy bowiem od końca wieku XVII były silnym ośrodkiem emigracji kalwińskiej, por. literatura naukowa, m.in.: Pierre-Paul Sagave, Berlin und Frankreich I685-185I, Berlin 1980; Monique Dannhauser, Aus Frankreich nach Deutschland. Die französischen Hugenotten und ihr Sproß Jacques-Egide Duhan de Jandun, Präzeptor des Preußenkönigs Friedrich II, Egelsbach 1999.

Io W eseju pt. De la littérature allemande, który opublikowany został w roku I780, Fryderyk II stwierdzit, że język niemiecki jest rozwlekły, niemelodyjny i ubogi w zwroty obrazowe. Na marginesie wspomnieć można, że dzieła Christiana Wolffa czytał w sporządzonym dla niego tłumaczeniu francuskim, por.: list Fryderyka II do Wilhelminy z 7 V I736, w: Friedrich der Grosse, t. I, s. 318.

II Por. literatura muzykologiczna, m.in.: Georg Thouret, Friedrich der Große als Musikfreund und Musiker, Leipzig I898; John Bourke, „Frederick the Great as Music-Lover and Musician”, Music and Letters 28 (1947) nr I, s. 63-77; Ernest Eugene Helm, Music at the Court of Frederick the Great, Norman 1960; Heinz Becker, „Friedrich der Große und die Musik”, w: Preußens großer König, red. Wilhelm Treue, Freiburg in Breisgau 1986, s. I50-160; Christoph Henzel, „Zu den Aufführungen der großen Oper Friedrichs II. von Preußen 1740-1756", Jahrbuch des Staatlichen Instituts für Musikforschung Preußischer Kulturbesitz 8 (1997), 47-53; Lena van der Hoven, Melanie Wald-Fuhrmann, La Musique c'est moi. Friedrichs II. klingender Weg zur historischen Größe, Berlin 20I3; Lena van der Hoven, Musikalische Repräsentationspolitik in Preußen (I688-1797). Hofmusik als Inszenierungsinstrument von Herrschaft, Kassel 2015, Sabine Henze-Döhring, Friedrich der Große. Musiker und Monarch, München 2012.

I2 Wzmożone zainteresowanie życiem i twórczością Wilhelminy datuje się od końca wieku XX. $\mathrm{Z}$ ważniejszych prac wymienić należy m.in.: Markgräfin Wilhelmine von Bayreuth und ihre Welt, red. Erich Bachmann, München 1959; Heinrich Thiel, Wilhelmine von Bayreuth. Die Lieblingsschwester 
Amalia (I723-87), także były uzdolnione muzycznie. Rodzeństwo talent muzyczny odziedziczyło zapewne po dziadkach ze strony ojca, królu Fryderyku I, który grał na flecie oraz królowej Zofii Charlotcie, która była znakomitą klawesynist$\mathrm{ką}^{13}$. Szczególnie silna więź emocjonalna łączyła Fryderyka ze starszą o trzy lata Wilhelminą. Zbliżyły ich do siebie nie tylko traumatyczne przeżycia z dzieciństwa związane z despotycznym i brutalnym ojcem, ale i zamiłowanie do nauki i sztuki. Podobnie jak Fryderyk, także Wilhelmina odznaczała się błyskotliwą inteligencją i była utalentowaną pisarką ${ }^{\mathrm{I}}$. Wysoko cenił ją Wolter, z którym korespondowała na tematy filozoficzne ${ }^{\mathrm{I}}$. W młodości Fryderyk i Wilhelmina razem muzykowali. Oboje pobierali naukę gry na klawesynie ${ }^{16}$ i lutni, ponadto Fryderyk grał na flecie. Zajmowali się także komponowaniem. Wspomnieć należy, że Wilhelmina była zdolną malarką.

W listopadzie I73I r. Wilhelmina poślubiła późniejszego margrabiego Brandenburgii-Bayreuth Fryderyka III (panował w 1. I735-63). W roku następnym wyjechała do Bayreuth, gdzie zajęła się organizacją życia kulturalnego. W jej działaniach wspierał ją mąż, który był człowiekiem wykształconym i wykazywał zainteresowania muzyczne, m.in. grał na flecie ${ }^{\mathrm{I7}}$. W Bayreuth Wilhelmina doskonaliła swoją grę na lutni u słynnego Silviusa Leopolda Weissa oraz podjęła naukę gry na skrzypcach ${ }^{\mathrm{I}}$. W roku 1756 razem z mężem założyła Akademię Sztuki, w której oprócz malarstwa i rzeźbiarstwa wykładano także muzykę.

Friedrichs des Großen, München 1967; Cordula Bischoff, „Markgräfin Wilhelmine von Bayreuth (1709-1758)", w: Deutsche Frauen der Frühen Neuzeit. Dichterinnen, Malerinnen, Mäzeninnen, red. Kerstin Merkel, Heide Wunder, Darmstadt 2000, s. 153-I67; Musik und Theater am Hofe der Bayreuther Markgräfin Wilhelmine, red. Peter Niedermüller, Reinhard Wiesend, Mainz 2002; Ruth Müller-Lindenberg, Wilhelmine von Bayreuth. Die Hofoper als Bühne des Lebens, Köln 2005; Uwe Oster, Wilhelmine von Bayreuth. Das Leben der Schwester Friedrichs des Großen, München 2005; Sabine Henze-Döhring, Markgräfin Wilhelmine und die Bayreuther Hofmusik, Bamberg 2009; Opernkonzeptionen zwischen Berlin und Bayreuth. Das musikalische Theater der Markgräfin Wilhelmine, red. Thomas Betzwieser, Würzburg 2016.

I3 Por:: H. Becker, „Friedrich der Große”, s. I50; Mary Oleskiewicz, „The Court of Brandenburg-Prussia”, w: Music at German Courts, I7IS-I760. Changing Artistic Priorities, red. Samantha Owens, Barbara M. Reul, Janice B. Stockigt, Woodbridge 20II, s. 79-130, zob. s. 80.

I4 Dzisiaj znana jest przede wszystkim jako autorka Pamiętników, zob.: Wilhelmine von Bayreuth. Eine preussische Königstochter. Glanz und Elend am Hofe des Soldatenkönigs in den Memoiren der Markgräfin Wilhelmine von Bayreuth, wyd. Ingeborg Weber-Kellermann, przekł. niem. Annette Kolb, Frankfurt am Main ${ }^{12} 2019$, wyd. pol. pt. Margrabina von Bayreuth Wilhelmina Fryderyka Zofia. Pamiętniki, przekt. Irena Wachlowska, Warszawa 1973.

I5 Por. np.: Georg Horn, Voltaire und die Markgräfin von Baireuth, Berlin 1865; Nichts Neues aus Bayreuth: Briefe der Markgräfin Wilhelmine an Friedrich II. und Voltaire, red. Günther Berger, Julia Wassermann, Berlin 2008.

I6 Wilhelmina była znakomitą klawesynistką. Już w wieku sześciu lat koncertowała, wzbudzając zachwyt słuchaczy podczas wieczorów muzycznych organizowanych przez jej matkę królową Zofię Dorotę hanowerską w pałacu Monbijou.

I7 Naukę gry na flecie pobierał m.in. u Michela Blaveta w Paryżu oraz Johanna Joachima Quantza, por: M. Oleskiewicz, „The Court”, s. 399.

I8 Por.: listy Wilhelminy do Fryderyka II z Is II I735 oraz 5 III I735, w: Friedrich der Grosse, t. I, s. 276 i 277. 
Po wyjeździe Wilhelminy do Bayreuth rodzeństwo prowadziło intensywną korespondencję, stanowiącą dowód ich wspólnego zamiłowania do filozofii, literatury, teatru i muzyki. W listach przesyłali sobie nawzajem partytury muzyczne (własne oraz innych kompozytorów) oraz wymieniali opinie o kompozycjach muzycznych i artystach (wokalistach i instrumentalistach). Zainteresowania muzyczne rodzeństwa koncentrowały się wyłącznie wokół muzyki kameralnej oraz opery.

\section{MUZYKA KAMERALNA}

Ważnym wydarzeniem w życiu Fryderyka II była podróż, którą jako szesnastoletni następca tronu odbył do Drezna na dwór króla polskiego i elektora saskiego Augusta II Mocnego. W czasie tej wizyty usłyszał słynną kapelę drezdeńską i poznał wybitnych muzyków, m.in. Carla Heinricha Grauna, a także Johanna Georga Pisendela i jego ucznia Johanna Joachima Quantza, którego gra na flecie wywarła silne wrażenie na młodym Fryderyku ${ }^{19}$. W pierwszym zachowanym liście do Wilhelminy z dnia 26 I 1728 r. Fryderyk relacjonował:

Zaprezentowałem się jako muzyk. Towarzyszyli mi Richter [Johann Christian], Buffardin [Pierre-Gabriel], Quantz, Pisendel i Weiss [Sylvius Leopold]. Podziwiam ich. To najwięksi artyści na dworze ${ }^{20}$.

Fryderyk zapewne zaprezentował się jako flecista ${ }^{2 I}$. W literaturze naukowej istnieje bowiem rozbieżność zdań co do tego, kiedy Fryderyk rozpoczął naukę gry na flecie. Ogół muzykologów twierdzi, że nastąpiło to w czasie pobytu Fryderyka w Dreźnie ${ }^{22}$. Quantz w swojej autobiografii ${ }^{23}$ lakonicznie zanotował, że następca tronu pruskiego podjął decyzję, by pobierać lekcje gry na flecie poprzecznym ${ }^{24}$. Na podstawie jego

I9 W maju 1728 r. August II złożył rewizytę w Berlinie. Towarzyszyli mu muzycy kapeli drezdeńskiej, zob. literatura naukowa, np. S. Salmonowicz, Fryderyk II, s. 20-2I. Edward R. Reilly podał błędną informację, że Fryderyk poznał Quantza dopiero w maju 1728 r., zob.: Edward R. Reilly, „Quantz, Johann Joachim", w: The New Grove Dictionary of Music and Musicians, red. Stanley Sadie, t. I5, London 1980, s. 495-497.

20 „Ich habe mich als Musiker hören lassen. Richter, Buffardin, Quantz, Pisendel und Weiss haben mitgespielt. Ich bewundere sie. Sie sind die besten Künstler bei Hofe”, zob.: „... solange wir zu zweit sind.”, s. 24 .

2I Mary Oleskiewicz wyraziła przypuszczenie, że Fryderyk wystąpił jako klawesynista, zob.: M. Oleskiewicz, „The Court”, s. 83.

22 Por.: G. Thouret, Friedrich der Große, rozdz. I; M. Oleskiewicz, „The Court”, s. 83; S. Henze-Döhring, Markgräfin Wilhelmine, s. 23; L. van der Hoven, M. Wald-Fuhrmann, La Musique c'est moi, s. 70; L. van der Hoven, Musikalische Repräsentationspolitik, s. 172.

23 Por.: Herrn Johann Joachim Quantzens Lebenslauf, von ihm selbst entworfen, w: Friedrich Wilhelm Marpurg, Historisch-Kritische Beyträge zur Aufnahme der Musik, t. I, Berlin 1754-55, s. 197-250, zob. s. 246.

24 Próba zatrudnienia Quantza w Berlinie nie powiodła się, ale wirtuoz uzyskał od Augusta II zgodę na wyjazd do Prus dwa razy do roku w celu udzielania Fryderykowi lekcji gry na flecie, zob. literatura muzykologiczna, m.in.: Marek Nahajowski, Sonaty fletowe Johanna Joachima Quantza. Między teoria a praktyką, Łódź 2013, s. 34-35. 
relacji nie możemy jednoznacznie stwierdzić, czy była to nauka od podstaw, czy też chodziło o doskonalenie techniki. Heinz Becker ${ }^{25}$ oraz Ernest Eugene Helm ${ }^{26}$ wyrazili pogląd, że w roku 1728 Fryderyk na flecie grał już biegle ${ }^{27}$. Zdaniem Helma, a także Johna Bourke'a, pierwszych lekcji gry na flecie udzielał Fryderykowi jego wychowawca J.-E. Duhan de Jandun ${ }^{28}$.

W roku 1732 Fryderyk rozpoczął organizowanie orkiestry kameralnej ${ }^{29}$. Pierwszym zatrudnionym muzykiem został kompozytor i skrzypek Johann Gottlieb Graun. W roku 1735 kapelmistrzem kapeli został jego brat, kompozytor i śpiewak Carl Heinrich Graun, z którym połączyła Fryderyka serdeczna przyjaźn. W tym samym roku Fryderyk poznał Carla Philippa Emanuela Bacha. W liście z 8 V I735 r. informował siostrę, że gości u siebie syna Bacha ${ }^{30}$, który znakomicie gra na klawesynie i jest bardzo dobrym kompozytorem, ale brak mu jeszcze wyrobionego smaku muzycznego. W roku 1738 C.Ph.E. Bach został klawesynistą w zespole Fryderyka i w jego służbie spędził trzydzieści lat. Ponadto do roku 1756, czyli do wybuchu wojny siedmioletniej, posadę w kapeli otrzymali tak wybitni muzycy, jak bracia Franz (František) Benda i Johann Georg (Jan Jiří) Benda, a także Christoph Schaffrath, Christoph Nichelmann, Johann Gottlieb Janitsch, Georg Czarth i Carl Friedrich Christian Fasch. W roku I74I zwolnienie ze służby na dworze w Dreźnie uzyskał Quantz i dołączył do kapeli króla pruskiego. W służbie królewskiej pozostał do końca życia, tj. trzydzieści dwa lata. Przez całe życie Fryderyka II i Quantza łączyły więzy przyjaźni, nie licząc lat I733-39, kiedy ich relacje uległy ochłodzeniu ${ }^{31}$. Kiedy bowiem po śmierci Augusta II w roku 1733 kapela drezdeńska została rozwiązana, Fryderyk oczekiwał, że Quantz zostanie członkiem jego zespołu, podobnie jak to uczynili F. Benda, Czarth i Schaffrath. Być może Quantz takie przyrzeczenie złożył i go nie dotrzymał ${ }^{22}$, bowiem rozczarowany Fryderyk w liście do siostry pisał:

25 Por.: H. Becker, „Friedrich der Große”, s. I5I.

26 Por.: E.E. Helm, Music at the Court, s. 5-6, 9. Helm powołał się na dokument, który przywołał Thomas Carlyle w swojej książce pt. History of Friedrich II of Prussia, Called Frederick the Great (t. I, London 1858, s. 383-384). Jest to sporządzony przez nauczycieli Fryderyka wykaz wydatków z września I719 roku. W wykazie tym znajduje się następujący zapis: „naprawa fletu - cztery grosze”.

27 Pogląd Beckera oraz Helma powtórzył Johannes Kunisch, autor jednej z fundamentalnych biografii poświęconej królowi Prus, zob.: J. Kunisch, Friedrich der Grosse, s. 82.

28 Por.: J. Bourke, „Frederick the Great”, s. 64; E.E. Helm, Music at the Court, s. 5.

29 Por. literatura muzykologiczna, m.in.: E.E. Helm, Music at the Court; M. Oleskiewicz, „The Court”.

30 Mowa tu oczywiście o Janie Sebastianie Bachu. Jak powszechnie wiadomo, Fryderyk II spotkał się z lipskim kantorem w Poczdamie w maju 1747 roku. Nazwisko J.S. Bacha nie pojawia się już więcej w korespondencji Fryderyka II i Wilhelminy.

3I Por. literatura muzykologiczna, m.in.: Albrecht Dümling, „Friedrich II, sein Lehrer Quantz und der deutsche Geschmack in der Musik", Zeitschrift für Religions- und Geistesgeschichte 56 (2004), nr 2, s. I24-I35; Ulrike Liedtke, "Johann Joachim Quantz und Friedrich II. Eine musikalische Verbindung”, w: Die Rheinsberger Hofkapelle von Friedrich II. Musiker auf dem Weg zum Berliner „Capell-Bedienten”, red. Ulrike Liedtke, Rheinsberg 2005.

32 Por.: M. Nahajowski, Sonaty fletowe, s. 35. 
Quantz zapewne cieszy się, że jego nowy władca [August III] objął tron królewski. A ponieważ on nie ma zamiaru przesiadać się z konia na osła, to uznał za stosowne, by złamać złożoną mi obietnicę. Jestem na niego tak zły, że nie chcę go znać33.

Relacje Fryderyka i Quantza ustabilizowały się ok. roku I739. Dla Fryderyka Quantz skomponował około trzysta koncertów fletowych. Ponadto organizował codziennie w pałacu Sanssouci wieczorne koncerty kameralne, na które zaproszenie otrzymywało małe grono słuchaczy ${ }^{34}$. Repertuar tych koncertów obejmował zazwyczaj kompozycje Fryderyka lub Quantza, a także utwory wokalne, m.in. autorstwa C.H. Grauna.

Wilhelmina również organizowała w Bayreuth cowieczorne koncerty ${ }^{35}$. $\mathrm{Na}$ tamtejszym dworze istniał zespół kameralny, którego członkami byli m.in. kompozytor i jeden z największych lutnistów swoich czasów Adam Falckenhagen oraz skrzypek Hofmann (imiona nieznane, być może Johann Georg ${ }^{36}$ ). Wilhelmina bardzo ceniła Hofmanna i często wspominała o nim w listach do brata. W jej opinii skrzypek ten swoimi umiejętnościami przewyższał nawet takich uznanych wirtuozów swoich instrumentów, jak Quantz i J.G. Graun ${ }^{37}$. Hofmann opuścił Bayreuth w roku I734. W roku 1737 Wilhelmina objęła kierownictwo muzyki dworskiej w Bayreuth i rozpoczęła reorganizację zespołu muzycznego ${ }^{38}$. Chociaż dysponowała skromniejszymi środkami finansowymi niż brat, to udało jej się zatrudnić uznanych w Niemczech wirtuozów. Wśród nich znaleźli się m.in. skrzypek i kompozytor Johann Daniel Leuthard, skrzypek Johann Wolfgang Kleinknecht oraz jego bracia - skrzypek i flecista Jakob Friedrich oraz flecista Johann Stephan. Dzięki staraniom Fryderyka

33 „Quantz freut sich vielleicht, dass sein neuer Herr den Königsthron bestiegen hat. Da er nicht vom Pferd auf den Esel steigen will, hat er es für angezeigt gehalten, mir sein Wort zu brechen. Ich bin so böse auf ihn, dass ich nichts mehr von ihm hören will”, list Fryderyka II do Wilhelminy z 6 XI I733, w: Friedrich der Grosse, t. I, s. I68.

34 Jednym z nielicznych gości zaproszonych na taki koncert był angielski uczony Charles Burney. W 1. 1770-72 Burney odbył muzyczną podróż po krajach niemieckich. W roku 1772 odwiedził Poczdam, zob.: Charles Burney, The Present State of Music in Germany, the Netherlands, and United Provinces: Or, the Journal of a Tour through those Countries, Undertaken to Collect Materials for a General History of Music, t. I-2, London 1773, wyd. 2 zmienione 1775, wyd. pol. pt. Obecny stan muzyki w Niemczech, Niderlandach i Zjednoczonych Prowincjach albo dziennik podróży przez owe kraje, podjętej celem zebrania materiatów dla „Powszechnej historii muzyki”, przekł. Jakub Chachulski, Warszawa 20I8. Na marginesie wspomnieć można, że w Starej Galerii Narodowej w Berlinie znajduje się obraz Adolpha von Menzla „Koncert fletowy Fryderyka Wielkiego w Sanssouci” (I850-52), który przedstawia jeden z takich koncertów. Por. też literatura naukowa, m.in.: Jost Hermand, Adolph Menzel. Das Flötenkonzert in Sanssouci. Ein realistisch geträumtes Preußenbild, Frankfurt am Main 1994; Gabriele Busch-Salmen, „Adolf Menzels «Flötenkonzert Friedrich der Großen in Sanssouci». Ein vertrautes Gemälde, I50 Jahre nach seiner Fertigstellung neu gesehen", Music in Art 28 (2003) nr I-2, s. I27-I46.

35 Por.: Wilhelmine von Bayreuth. Eine preussische Königstochter, s. 434.

36 Por.: S. Henze-Döhring, Markgräfin Wilhelmine, s. I32. Z listu Wilhelminy do Fryderyka II z I6 VII I732 r. (w: Friedrich der Grosse, t. I, s. 98) dowiadujemy się, że Hofmann przez dziesięć lat przebywał we Włoszech, a na przełomie roku 1726/27 spotkał w Paryżu Quantza.

37 Por.: list Wilhelminy do Fryderyka II z I2 VII I732, w: „... solange wir zu zweit sind.”, s. 4I.

38 Por.: list Wilhelminy do Fryderyka II z grudnia I737, w: ibid., s. I33. 
ofertę pracy w Bayreuth przyjął flecista Christian Friedrich Döbbert. Kapelmistrzem został skrzypek i kompozytor Johann Pfeiffer (I697-176I), który funkcję tę pełnił do końca życia. Ponadto udzielał on Wilhelminie lekcji śpiewu. Obowiązki nadwornego kompozytora w 1. 1737-38 pełnił Giuseppe Antonio Paganelli (I7IOok. 1763)39. Wilhelmina bardzo ceniła twórczość tego kompozytora. Jej opinii nie podzielał natomiast Fryderyk - jego zdaniem Wilhelmina od dawna nie miała okazji posłuchać dobrej muzyki i z tego powodu jej ocena osiągnięć Paganellego była niewłaściwa ${ }^{40}$.

Aby wzbogacić repertuar wykonywanych w Bayreuth utworów Fryderyk wysyłał siostrze m.in. koncerty fletowe Quantza oraz koncerty klawesynowe Schaffratha, który należał do jednych z największych klawesynistów swoich czasów ${ }^{41}$, a także kantaty C.H. Grauna, F. Bendy i Quantza. Ponadto muzycy berlińscy, m.in. Quantz, Franz Benda, Schaffrath oraz bracia Graunowie, regularnie odwiedzali Bayreuth i udzielali lekcji muzykom działającym na tamtejszym dworze ${ }^{42}$. Na marginesie wspomnieć należy, że w swojej rezydencji w Bayreuth Wilhelmina gościła także m.in. Johanna Adolfa Hassego i jego żonę śpiewaczkę Faustinę Bordoni ${ }^{43}$.

Najwyższy zachwyt Wilhelminy wzbudzał kunszt artystyczny Quantza. Na przykład w dniu I8 X 1732 roku pisała do brata:

To bardzo uprzejme z Twojej strony, że postarałeś się dla mnie o koncerty Quantza. On jest muzycznym bogiem. Wiele tutejszych osób, które go słyszały, jest nim oczarowanych ${ }^{44}$.

Quantz odwiedzał Bayreuth wielokrotnie, m.in. był tam na początku roku 1736. Relacje Fryderyka i wirtuoza były wówczas chłodne. Fryderyk w listach do siostry pisał, że Quantz jest zarozumiały i pyszny, a Wilhelmina schlebia jego próżności ${ }^{45}$. Zdaniem Wilhelminy nieporozumienia między przyjaciółmi wynikały z zazdrości, bowiem Quantz w rozmowie z nią wyjawił, że Fryderyk jest równie doskonałym flecistą jak on $\operatorname{sam}^{46}$. A Quantz nie znosił konkurencji, nawet ze strony następcy tronu

39 Por. m.in.: Erich Schenk, Giuseppe Antonio Paganelli. Sein Leben und seine Werke, nebst Beiträgen zur Musikgeschichte Bayreuths, Salzburg 1928.

40 Por.: list Fryderyka II do Wilhelminy z I6 IV I737, w: Bagatellen aus Berlin, s. 82.

4I Por. literatura muzykologiczna, m.in.: Hartmut Grosch, „Christoph Schaffrath. Komponist - Cembalist - Lehrmeister”, w: Die Rheinsberger Hofkapelle von Friedrich II, red. Ulrike Liedtke, Rheinsberg I995, ${ }^{2} 2005$, s. 203-238.

42 Por. np. listy Fryderyka II i Wilhelminy z 8 XII I732 (w: „.. solange wir zu zweit sind.”, s. 49), I2 IX I733 (w: Friedrich der Grosse, t. I, s. I54), I9 III I734 (w: ibid., s. 202), I4 VI I734 (w: „... solange wir zu zweit sind.", s. 80).

43 Por.: S. Henze-Döhring, Markgräfin Wilhelmine, s. I66, I67.

44 „Es ist zu gütig von Dir, mir Konzerte von Quantz zu verschaffen. Er ist der Gott der Musik. Mehrere hiesige Personen, die ihn gehört haben, waren bezaubert von ihm”, zob.: „... solange wir zu zweit sind.”, s. 43 .

45 Por.: listy Fryderyka II do Wilhelminy np. z I2 I I736 (w: Friedrich der Grosse, t. I, s. 308) oraz 22 II I736 (w: Bagatellen aus Berlin, s. 59).

46 Por.: listy Wilhelminy do Fryderyka II z 29 I 1736 oraz 7 II I736, w: Friedrich der Grosse, t. I, s. 3IO i 3 II. 
pruskiego. W istocie liczne, nawet te niepodejrzane o pochlebstwo ówczesne opinie stwierdzały, że Fryderyk II grał doskonale na flecie ${ }^{47}$.

Inni muzycy zatrudnieni w kapeli Fryderyka także mieli trudne charaktery. W dniu Io XII I737 r. Fryderyk donosił bowiem siostrze:

Muzycy są przeważnie humorzaści i swarliwi. Niech tylko dwoje ma takie same umiejętności, to natychmiast stają się rywalami. [...] Artyści często wystawiają moją cierpliwość na próbę. Nieustannie trzeba rozwiązywać spory i znosić czyjeś humory. Benda jest ze wszystkich muzyków najbardziej konfliktowy. Dlatego w ostatnim roku nie wysłałem go do Ciebie do Bayreuth. On jest głównym buntownikiem i muszę przeważnie jego mieć na oku. Zatem nie dziwi mnie to, że Twoi artyści zachowują się tak samo. Nie należy im za bardzo schlebiać. To najlepszy sposób, by przywołać ich do rozsądku $[\ldots]^{48}$.

Wspomniany w cytacie Franz Benda odwiedzał Bayreuth wielokrotnie ${ }^{49}$. M.in. w roku 1734 spędził tam cztery i pół miesiąca. Wilhelmina bardzo go ceniła. W jej opinii instrumentaliści niemieccy posiadali większe umiejętności niż muzycy włoscy. Jak bowiem pisała:

Nigdy nie będę szukać muzyki instrumentalnej we Włoszech. Mimo całej wrzawy, jaką czynią wokół swojego Tartiniego, uważam, że Graun i Benda grają bardziej czarująco ${ }^{50}$.

W liście z 2 V I734 r. wyznała bratu, że muzyka nie sprawia jej żadnej przyjemności odkąd Benda wyjechał, ale przyznała, że gra Pfeiffera jest bardziej zadowalająca, odkąd usłyszał tego muzyka. W odpowiedzi Fryderyk napisał, że Benda w istocie jest dobrym kompozytorem, ale Graun go przewyższa ${ }^{51}$.

Jak już wspomniano wyżej, zarówno Fryderyk, jak i Wilhelmina zajmowali się komponowaniem. Fryderykowi nauki kompozycji udzielał C.H. Graun i Quantz, a Wilhelminie Hofmann, a następnie Pfeiffer.

Pierwsze kompozycje Fryderyka powstały w roku I732. W liście z 8 XII I732 r. oznajmił siostrze, że został kompozytorem i ukończył właśnie swój drugi koncert. W odpo-

47 Por. literatura muzykologiczna, m.in.: Georg Müller, Friedrich der Grosse, seine Flöten und sein Flötenspiel, Berlin 1932; E.E. Helm, Music at the Court, s. 29-39; Andrea Kapell Loewy, „Frederick the Great. Flutist and Composer", College Music Symposium 30 (I990) nr 2, s. II7-I25.

48 „Die Herren Musiker sind zumeist launisch und zänkisch. Können zwei gleich viel, so werden sie sofort zu Nebenbuhlern. [...] Meine Künstler stellen meine Geduld oft auf die Probe. Stets ist ein Aufruhr zu dämpfen und irgeneine Laune zu besiegen. Benda ist von allen der unverträglichste. Deshalb habe ich ihn Dir letztes Jahr nicht nach Baireuth geschickt. Er ist der Hauptaufrührer, und ich muss ihn am meisten im Auge behalten. Da wundert es mich nicht, dass es mit Euren Künstlern ebenso steht. Um sie zur Vernunft zu bringen, ist das beste Mittel, ihnen nicht zu sehr zu schmeicheln [...]”, zob.: „... solange wir zu zweit sind.", s. 134 .

49 Por. także literatura muzykologiczna: Hans-Joachim Bauer, „František Benda, ein Musiker aus Berlin zu Gast in Bayreuth”, w: Musik und Theater am Hofe der Bayreuther Markgräfin Wilhelmine, red. Peter Niedermüller, Reinhard Wiesend, Mainz 2002, s. 59-66.

50 „[...] werde ich nie die Instrumentalmusik in Italien suchen, und trotz alles Aufhebens, das sie von ihrem Tartini machen, bin ich überzeugt, dass Graun und Benda weit reizvoller spielen”, list Wilhelminy do Fryderyka II z 29 XI I739, w: Friedrich der Grosse, t. I, s. 429.

5I Por.: list Fryderyka II do Wilhelminy z 28 III I734, w: Bagatellen aus Berlin, s. 4I. 
wiedzi Wilhelmina pisała, że ją także całkowicie pochłania kompozycja, ale nauka idzie jej powoli, ponieważ Hofmann nie jest tak biegły w kompozycji jak Graun ${ }^{52}$.

Wilhelmina komponować zaczęła w roku $173 \mathrm{I}^{53}$. Niestety, zachowały się tylko nieliczne z jej utworów. W roku $1753 \mathrm{w}$ zamku w Bayreuth wybuchł pożar, który pochłonął m.in. zbiór nut, w tym kompozycje Wilhelminy ${ }^{54}$. Z jej utworów kameralnych zachowała się jedynie sonata na flet i basso continuoss. W korespondencji Wilhelmina niewiele pisała o swoich kompozycjach ${ }^{56}$.

Fryderyk tworzył przede wszystkim utwory fletowe, których fragmenty wysyłał Wilhelminie ${ }^{57}$. Na przykład 7 III I735 r. pisał:

Czas upływa mi na lekturze i muzyce. Pozwoliłem sobie przesłać Ci dawno obiecane solo. Proszę, powiedz mi, czy Ci się podoba. Bas napisałem sam, bez pomocy innej ręki $[\ldots]^{58}$.

Parę miesięcy później informował siostrę, że napisał symfonię̧5. Podkreślił, że przy jej wykonaniu ważne jest osiagnięcie prawidłowego efektu piano. Pod koniec roku 1738 Fryderyk tak oto oceniał swoje umiejętności kompozytorskie:

Moje komponowanie jest niewiele warte. Moje umiejętności wprawdzie są wystarczające, by stworzyć fletową arię, ale musiałbym lepiej znać język włoski, bym mógł spróbować moich sił w napisaniu kantaty. A Graun pisze tak wspaniałe utwory, że moich własnych nie cierpię ${ }^{60}$.

Utwory muzyczne Fryderyk II pisał na użytek prywatny i, w przeciwieństwie do dzieł literackich, nie opublikował ich $^{61}$. Jego zachowana spuścizna kompozytorska

52 Por.: list Wilhelminy do Fryderyka II z I6 XII I732, w: „... solange wir zu zweit sind. ”, s. 49.

53 Por.: Wilhelmine von Bayreuth. Eine preussische Königstochter, s. 217.

54 Por.: list Wilhelminy do Fryderyka II z I7 II I753, w: „... solange wir zu zweit sind. ”, s. 234.

55 Wilhelmina do niedawna uchodziła za autorkę koncertu klawesynowego g-moll. Jak wykazała Sabine Henze-Döhring, jest to kompozycja Johanna Gotthilfa Jänichena, zob.: S. Henze-Döhring, Markgräfin Wilhelmine, s. 42-52.

56 Także w Pamiętnikach Wilhelmina rzadko wspomina o swojej pracy kompozytorskiej.

57 Por.: listy Fryderyka II do Wilhelminy np. z 7 III 1735 (w: „... solange wir zu zweit sind.”, s. IOO) oraz I7 III 1736 (w: Bagatellen aus Berlin, s. 62).

58 „Mein Zeitvertreib ist stets Lektüre und Musik. Ich erlaube mir, Dir das lang angekündigte Solo zu senden. Bitte sage mir, ob es Dir gefällt oder nicht. Der Bass ist ganz von mir, ohne jede Verbesserung von fremder Hand [...]”, zob.: „... solange wir zu zweit sind.”, s. Ioo. Według relacji Johanna Friedricha Reichardta król notował tylko głos najwyższy, głosy środkowe natomiast dopisywali m.in. Quantz lub C.H. Graun, zob.: Johann Friedrich Reichardt, Musikalisches Kunstmagazin, t. 2, Berlin I79I, s. 40. Reichardt od roku 1775 pełnił funkcję kapelmistrza Opery berlińskiej.

59 Fryderyk swoje kompozycje, m.in. dwie symfonie, przesyłał także grafowi von Schaumburg-Lippe, który amatorsko zajmował się komponowaniem. W dniu 24 XI 1738 r. Fryderyk napisał do grafa, że wykonanie jego symfonii wymaga udziału znakomitych skrzypków, zob.: Correspondance de Frédéric avec le comte de Schaumbourg-Lippe, s. 208.

60 „Meine Komposition ist nicht viel wert. Mein Können reicht zwar hin, um mir irgend eine Flötenarie zu fabrizieren, aber ich müsste besser Italienisch können, um mich an Kantaten heranzuwagen, und Graun schreibt so prachtvolle, dass ich die eigenen nicht ausstehen kann, wenn ich welche von ihm gehört habe", list Fryderyka II do Wilhelminy z I2 XI I738, w: Friedrich der Grosse, t. I, s. 387.

6I Fryderyk II w poetyckim utworze Épitre à mon esprit, który stanowi podsumowanie jego artystycznej działalności, swoje kompozycje muzyczne pominął milczeniem, zob.: Fryderyk II, Épître XX. à mon esprit, w: Oeuvres de Frédéric le Grand, red. Johann David Erdmann Preuss, t. IO, Berlin I849, s. 213-222. 
obejmuje I2I sonat i cztery koncerty. Nie zachowały się symfonie oraz kantaty, które zaczął pisać po roku I738. W przeciwieństwie do siostry Fryderyk II nigdy nie podjął próby napisania opery.

\section{OPERA}

W roku I728 Fryderyk podczas wspomnianej już wizyty w Dreźnie po raz pierwszy był na przedstawieniu operowym. Wystawiono wówczas operę Calandro Giovanniego Alberta Ristoriego ${ }^{62}$. Od tej pory zamiłowanie do opery włoskiej będzie towarzyszyć Fryderykowi II przez całe życie.

Znamienne jest to, że monarcha nie cenił francuskiej twórczości operowej, mimo że był miłośnikiem kultury tego kraju ${ }^{63}$. Pogląd Fryderyka podzielała Wilhelmina. Oboje byli zgodni co do tego, że kompozytorzy francuscy, m.in. Jean-Baptiste Lully, André Campra i André Destouches, nie zasłużyli na to, by ich nazwiska zostały wymienione w pracy Évrarda Titona du Tillet pt. Le Parnasse françois ${ }^{64}$.

Jedną z pierwszych decyzji Fryderyka II po objęciu tronu królewskiego była budowa gmachu operowego (dzisiejsza Staatsoper Unter den Linden) ${ }^{65}$. Na polecenie króla C.H. Graun udał się w trwającą prawie rok podróż do Włoch, by skompletować zespół wokalistów. W opinii bowiem Fryderyka tylko Włosi potrafili dobrze śpiewać ${ }^{66}$. Zadanie, które król powierzył Graunowi, okazało się trudne. W liście z 25 XI I74I r. Fryderyk nie krył rozczarowania, że poziom nowo zatrudnionych wokalistów, z wyjątkiem Marii Giovanny Gasparini ${ }^{67}$, jest przeciętny. Nadzieje Fryderyka zawiódł m.in. Giuseppe Santarelli, któremu Fryderyk w roku następnym nie przedłużył angażu. Sytuacja poprawiła się rok później, gdy do zespołu dołączyły gwiazdy ówczesnych scen operowych, a mianowicie: Benedetta Emilia Molteni, Antonio Romani, Antonio Uberi (zwany Porporino) i Paolo Bedeschi (zwany Paolino) ${ }^{68}$.

62 W literaturze naukowej podawana jest często błędna informacja, że wystawiono wówczas operę Cleofide J.A. Hassego, por.: E.E. Helm, Music at the Court, s. 9, 239; H. Becker, „Friedrich der Große”, s. I53; Heinz Becker: „Friedrich II”, w: Die Musik in Geschichte und Gegenwart, red. Friedrich Blume, t. 4, Kassel 1955, szp. 955. Jednakże premiera tej opery miała miejsce dopiero I3 IX I73I r., zob.: Alina Żórawska-Witkowska, Muzyka na polskim dworze Augusta III, cz. I, Lublin 20I2, s. 326; M. Oleskiewicz, „The Court”, s. 8I.

63 W opinii Fryderyka II Francuzi wyprzedzali Niemców we wszystkich dziedzinach o sto lat, zob.: list do Wilhelminy z I6 XI 1746, w: „... solange wir zu zweit sind.”, s. 20I.

64 Por: list Wilhelminy do Fryderyka II z 29 XI 1739 oraz list Fryderyka II do Wilhelminy z I4 XII I739, w: Friedrich der Grosse, t. I, s. 428 i 430. Por. także literatura naukowa, m.in. Judith Colton, The Parnasse François: Titon du Tillet and the Origins of the Monument to Genius, New Haven I979.

65 Architektem był Georg Wenzeslaus von Knobelsdorff, który zaprojektował budynek według szkicu Fryderyka II.

66 Pierwszą śpiewaczką niemiecką, która zachwiała przekonanie Fryderyka II, że tylko Włosi umieją śpiewać, była Gertrud Elisabeth Schmeling-Mara. W Operze berlińskiej została zatrudniona w roku I77I.

67 Maria Giovanna Gasparini pozostała w służbie Fryderyka II do roku 1776 i do końca życia cieszyła się jego wielkim uznaniem.

68 Por. np. list Fryderyka II do Wilhelminy z I4 XII 1739 oraz 20 X I742, w: Bagatellen aus Berlin, s. I07. Por. także literatura muzykologiczna, m.in.: Italienerinnen und Italiener am Hofe Friedrichs II (I740-I786), red. Rita Unfer Lukoschik, Berlin 2008. 
Pierwsze przedstawienie w nowo otwartym gmachu odbyło się 7 XII I742 roku. Pokazano wówczas operę Cesare e Cleopatra C.H. Grauna. Dwa dni przed premierą Fryderyk pisał do Wilhelminy, że był na próbie, która zapowiada się obiecująco muzyka jest znakomita, a chór i balet wspaniałe ${ }^{69}$. Przedstawienie odniosło wielki sukces. Według relacji Fryderyka publiczność była bardzo zadowolona, a on sam nigdy nie oglądał tak wspaniałego przedstawienia. Śpiewacy oraz zespół baletowy zaprezentowali się znakomicie ${ }^{70}$.

Do czasu wybuchu wojny siedmioletniej co roku miały miejsce zazwyczaj dwie premiery operowe. Repertuar obejmował dzieła ulubionych kompozytorów króla, a mianowicie Johanna Adolfa Hassego i Carla Heinricha Grauna, którzy należeli do czołowych twórców operowych w drugiej połowie wieku XVIII ${ }^{71}$ oraz byli przedstawicielami stylu opery włoskiej $j^{72}$.

Pomimo licznych obowiązków państwowych Fryderyk II mocno angażował się w przygotowania spektakli operowych. Nie szczędził przy tym kosztów, bowiem Opera berlińska miała być demonstracją potęgi Prus. Ambicją króla było konkurowanie z teatrami operowymi w Dreźnie, Wiedniu i Paryżu. Fryderyk II osobiście rozstrzygał wszystkie kwestie teatralne dotyczące m.in. zatrudnienia wokalistów, instrumentalistów i tancerzy, a także wyboru kostiumów i dekoracji. Ponadto nadzorował pracę librecistów ${ }^{73}$, wizytował próby, a nawet sam pracował z wokalistami nad precyzją wykonania, m.in. ćwiczył z Porporino prawidłowe wykonanie fragmentów w tempie adagio ${ }^{74}$. Fryderyk II był pod wielkim wrażeniem umiejętności wokalnych tego artysty. W roku 1743 wyraził przekonanie, że Porporino niebawem dołączy do grona największych europejskich śpiewaków operowych. W tymże roku w zespole Opery znalazł się Felice Salimbeni, jeden z najwybitniejszych wokalistów swoich czasów, który występował m.in. na deskach operowych Rzymu, Wiednia i Drezna. Był znakomitym interpretatorem oper Hassego. Jego występy wzbudzały ogromny entuzjazm publiczności. W połowie roku I746 Fryderyk pisał do siostry, że

69 Por.: list Fryderyka II do Wilhelminy z 5 XII 1742, w: Bagatellen aus Berlin, s. I09.

70 Por.: list Fryderyka II do Wilhelminy z 8 XII 1742, w: ibid., s. IIo.

7I Por.: Johann Georg Sulzer, Allgemeine Theorie der schönen Künste, t. 2, Lipsk 1774, zob. także literatura muzykologiczna, m.in.: Albert Mayer-Reinach, "Carl Heinrich Graun als Opernkomponist”, Sammelbände der Internationalen Musikgesellschaft I (1900) nr 3, s. 446-529.

72 Por. literatura muzykologiczna, m.in.: Italian Opera in Central Europe I6I4-I780, t. 3, red. Norbert Dubowy, Corinna Harr, Alina Żórawska-Witkowska, Berlin 2007.

73 C.H. Graun w liście do F. Assenbacha z 20 VIII 1742 r. wspominał, że poeta dworski Giovanni Gualberto Bottarelli na żądanie króla trzykrotnie poprawiał libretto opery Cesare e Cleopatra, zob.: Briefe Carl Heinrich Grauns, red. Berthold Kitzig, Zeitschrift für Musikwissenschaft 9 (1926/27), s. $385-405$, cyt. s. 404 .

74 W liście z Is III 1743 Fryderyk II informował Wilhelminę, że dla swojego ucznia Porporino napisał dwie kantaty i ma zamiar napisać jeszcze kilka arii do opery Artaserse, zob.: Correspondance de Frédéric, s. II7. Obie kantaty zaginęły, a do współpracy króla i Grauna przy operze Artaserse nie doszło, zob.: H. Becker, „Friedrich der Große”, szp. 957. Na marginesie trzeba dodać, że Porporino był uczniem Nicola Porpory. 
aktualnie najwybitniejszym śpiewakiem jest Salimbeni, a czas takich artystów jak Faustina Bordoni i Giovanni Maria Carestini przeminął. Salimbeni opuścił zespół Opery berlińskiej w roku I750, po tym jak Fryderyk II obarczył go winą za porażkę opery Coriolan. Jego miejsce zajął wspomniany wyżej Carestini, który w Berlinie nie odniósł większych sukcesów.

W roku 1747 w Operze berlińskiej zatrudniona została słynna w całej Europie Giovanna Astrua. W dniu 20 VI 1747 r. Fryderyk z dumą pisał do siostry:

Astrua, ta wokalistka jest naprawdę zdumiewająca; wykonuje arpeggia jak skrzypek, z niezwykłą szybkością śpiewa wszystko, co zagra flet. Natura, odkąd zaczęła tworzyć gardła, nigdy nie stworzyła czegoś porównywalnego. Pani ta oprócz talentu i pięknego głosu posiada jeszcze jedną zaletę, a mianowicie jest bardzo rozsądna, dobroduszna i mądra [... $]^{75}$.

W Berlinie Astrua zadebiutowała w roku 1748 w operze Grauna pt. Galatea ed Acide. Z Operą berlińską związana była do końca życia, tj. do roku I757.

Opera była również wielką pasją Wilhelminy. W liście z dnia 4 VIII I747 r. wyznała:

Nic nie sprawia mi większej przyjemności niż piękna opera. Moje uszy prowadzą miłe dźwięki w głąb mojego serca ${ }^{76}$.

Z jej inicjatywy wybudowano w Bayreuth gmach operowy, który otwarty został w roku I748. Wilhelmina bardzo angażowała się w przygotowania spektakli operowych ${ }^{77}$. Podobnie jak brat, najwyżej ceniła talent śpiewaków włoskich. W opinii Wilhelminy:

Jeżeli raz słyszało się dobry głos włoski, to niemieckie głosy nie podobają się już tak bardzo. Ten naród w sposób wyjątkowy wydobywa dźwięk; trudno to uzyskać, jeżeli ktoś od małego nie kształcił się we Włoszech. Ponadto Niemcy nie mają wyraźnej wymowy, która sprawia, że głos Włochów jest mocniejszy ${ }^{78}$.

W roku 1738 zatrudniła grupę wokalistów włoskich, wśród których znaleźli się m.in. Margherita Giacomazzi (zwana Furiosa) oraz Giacomo Zaghini, którzy m.in. występowali w Wenecji w operach Antonia Vivaldiego ${ }^{79}$. Wzorem brata także

75 „Astrua, cette chanteuse est réellement surprenante; elle fait des arpeggios comme les violons, elle chante tout ce que la flûte joue avec une agilité et une vitesse infinie. Jamais la nature, depuis qu'elle mèle de fabrique des gosiers, n'en a fait de pareil. Cette femme, avec tous ses talents et sa belle voix, a encore le mérite d'être très raisonable, bonne et sage [...]", zob.: Correspondance de Frédéric, s. I60.

76 „Nichts macht mir mehr Vergnügen als eine schöne Oper; meine Ohren leiten die holden Töne bis in mein tiefstes Herz”, zob.: „... solange wir zu zweit sind.”, s. 208.

77 Por.: np. listy Wilhelminy do Fryderyka II z 28 IV 1738 oraz I5 X I743, w: ibid., s. 137 i 174.

78 „Hat man einmal eine gute italienische Stimme gehört, so gefallen einem die Deutschen nicht mehr so. Dies Volk hat etwas einziges im Ton, das sich schwer nachahmen lässt, wenn man nicht von klein auf in Italien ausgebildet worden ist. Zudem ist die deutliche Aussprache, wodurch ihre Stimme noch stärker zur Geltung kommt, den Deutschen nicht gegeben”, list Wilhelminy do Fryderyka II z 29 XI I739, w: Friedrich der Grosse, t. I, s. 429.

79 Por.: ibid., a także literatura muzykologiczna, m.in.: Saskia Maria Woyke, „Virtuosinnen und ein Virtuose in Bayreuth - Anmerkungen zu den von der Markgräfin Wilhelmine engagierten Sängerinnen und Sängern", w: Opernkonzeptionen zwischen Berlin und Bayreuth, s. 55-70. 
Wilhelmina szkoliła swoich wokalistów ${ }^{80}$. Szczególny zachwyt wzbudzał w niej talent Zaghiniego, który, jak pisała, ma bardzo mocny głos i z niezwykłą łatwością wykonuje najtrudniejsze utwory oraz bardzo długie tryle, co odpowiada gustom ówczesnej publiczności ${ }^{81}$. Podkreślała przy tym, że jest on człowiekiem bardzo rozważnym i spokojnym, co jest cechą rzadko spotykaną u Włocha. Wilhelmina wielokrotnie żaliła się bratu, że praca z artystami włoskimi jest trudna z uwagi na ich żywiołowy i wybuchowy temperament ${ }^{82}$. Fryderyk miał podobne doświadczenia. W jego liście z dnia 9 V I740 r. czytamy bowiem:

Nie dziwię się, że masz zmartwienie ze swoimi włoskimi muzykami. Oni są najgorszym prezentem, jaki ludzkość otrzymała od gniewnego nieba. Przyjemność płynąca z ich śpiewu nie kompensuje hałasu, który czynią swoimi kłótniami i swarami ${ }^{83}$.

Przedstawienia operowe w Bayreuth odbywały się w nieregularnych odstępach czasu. Repertuar wykonywanych oper był bardziej zróżnicowany od repertuaru wykonywanego w Berlinie, bowiem oprócz dzieł Hassego i Grauna, których partytury dostarczał Wilhelminie Fryderyk ${ }^{84}$, wystawiano m.in. kompozycje Paganellego. Jak już wspomniano wyżej, Fryderyk nie cenił twórczości tego kompozytora. W dniu I2 XI I738 r. pisat:

Ponieważ pytasz mnie o moje zdanie o Paganellim, to będę szczery: jego opera, którą słyszałem w Brunszwiku, była nic niewarta. Tylko trzy arie były dobre, a i te nie były jego autorstwa. Jedną napisał Hasse, drugą [Leonardo] Vinci, a trzecia, jeżeli się nie mylę, pochodziła z jednej z włoskich oper. Komponowanie nie jest jego mocną stroną. Akompaniamenty są niewłaściwe i ranią słuch. Ale mówię tylko o operze, którą słyszałem, a nie o muzyce, którą skomponował w Bayreuth ${ }^{85}$.

Ponadto na dworze w Bayreuth można było usłyszeć m.in. dzieła André Campry, Niccolò Jommellego, Marii Antonii Walpurgis, a także utwory samej

80 Por. np.: list Wilhelminy do Fryderyka II z 25 XII 1746, w: Correspondance de Frédéric, s. I50. Por. także literatura muzykologiczna: R. Müller-Lindenberg, Wilhelmine von Bayreuth, s. 98-99.

8I Por.: list Wilhelminy do Fryderyka II z marca 1738, w: Friedrich der Grosse, t. I, s. 374.

82 Np. w liście do Fryderyka z II XI I838 pisała: „Nie ma nic piękniejszego od głosu włoskiego, ale z tymi ludźmi trudno sobie dać radę” („Es gibt nichts Schöneres als eine italienische Stimme, aber es ist schwer, mit diesen Leuten fertig zu werden”), zob.: ibid., s. 386.

83 „Ich wundere mich nicht über den Ärger, den Sie mit Ihren italienischen Musikern haben: Sie sind das schlimmste Geschenk, das die Menschheit vom Zorn des Himmels erhalten kann. Das Vergnügen, das sie schenken, wenn man sie hört, wiegt den Lärm, den sie andauernd mit ihren Streitereien und ihrer Unzufriedenheit veranstalten, nicht auf", zob.: Bagatellen aus Berlin, s. 98.

84 Por. np.: list Fryderyka II do Wilhelminy z 2 II I75I, w: Correspondance de Frédéric, s. 201.

85 „Da Du mich nach meinem Urteil über Paganelli fragst, sage ich Dir ganz offen, seine Oper, die ich in Braunschweig gehört habe, taugte nichts. Nur drei Arien waren gut, und die waren nicht von ihm. Die eine stammte von Hasse, die andere von Vinci und die dritte, wenn ich nicht irre, aus einer italienischen Oper. Das Komponieren ist leider nicht seine Stärke. Die Begleitungen sind meist fehlerhaft, und das tut dem Ohr weh. Ich spreche aber nur von der Oper, die ich von ihm gehört habe, und nicht von der Musik, die er etwa in Baireuth komponiert hat", zob.: Friedrich der Grosse, t. I, s. $387-388$. 
Wilhelminy. Niestety, zachowała się tylko jedna jej opera pt. Argenore, która wykonana została w maju w roku $\mathrm{I}_{74 \mathrm{O}^{86}}$. W marcu tegoż roku Wilhelmina zapowiedziała bratu przesłanie jej fragmentów. W listach Fryderyk zapewniał, że kompozycja siostry sprawi mu największą radość i będzie milsza od wszystkich arii Hassego i Grauna. Obiecał także dokonanie obiektywnej i surowej oceny jej dzieła $^{87}$. Niestety, w następnych listach ani Fryderyk, ani Wilhelmina nie wspominają już o Argenore. W roku 1743 Wilhelmina poinformowała brata, że pracuje nad nową operą.

Sam Fryderyk II nie stworzył opery. Jest natomiast autorem pojedynczych arii w operach skomponowanych m.in. przez Grauna (np. Demofoonte) ${ }^{88}$.

Fryderyk II i Wilhelmina dużą wagę przywiązywali do wysokiej pod względem literackim jakości librett operowych. Oboje też pisali libretta w języku francuskim, które tłumaczone były na język włoski. W roku I75I Wilhelmina w uznaniu jej osiągnięć literackich została przyjęta w poczet rzymskiej Accademia dell'Arcadia, której członkiem był m.in. Pietro Metastasio. Wilhelmina w listach do brata niewiele pisała o swojej pracy literackiej. Na przykład w listopadzie I750 r. lakonicznie poinformowała go, że pracuje nad adaptacją na libretto sztuki Woltera pt. Sémiramis. Pracę nad librettem ukończyła dwa lata później i przedstawiła je Hassemu, który nie podjął się napisania do niego muzyki. W dniu 9 XI 1752 r. Wilhelmina pisała do brata:

Hasse nie mógł jej skomponować. Musiałam ją dać jednemu Włochowi, który nie stworzył nic wielkiego ${ }^{89}$.

Kim był ów włoski kompozytor, niestety nie wiemy ${ }^{90}$. Premiera Sémiramis, która odbyła się w roku I753, odniosła sukces. Jak informowała Wilhelmina, aktorzy zagrali i zaśpiewali znakomicie ${ }^{9 \mathrm{I}}$.

86 Szczegółowe omówienie opery Argenore znajduje się w: R. Müller-Lindenberg, Wilhelmine von Bayreuth, s. I03-I36. Por. także: Hans-Joachim Bauer, Rokoko-Oper in Bayreuth. "Argenore” der Markgräfin Wilhelmine, Laaber 1983; Wolfgang Hirschmann, „Italienische Opernpflege am Bayreuther Hof. Der Sänger Giacomo Zaghini und die Oper Argenore der Markgräfin Wilhelmine”, w: Italienische Musiker und Musikpflege an deutschen Höfen der Barockzeit, red. Friedhelm Brusniak, Köln I995, s. II7-I53; Susanne Vill, „Argenore inszenieren. Die Oper von Wilhelmine von Bayreuth im Markgrafentheater Erlangen”, w: Théâtre, Musique et Arts dans les Cours Européennes de la Renaissance et du Baroque, red. Kazimierz Sabik, Warszawa 1997, s. 517-536; Wolfgang Hirschmann, „Von der Zuständigkeit der Dilettantin: Wilhelmines Argenore (1740) und die Musikgeschichte des I8. Jahrhunderts", w: Opernkonzeptionen zwischen Berlin und Bayreuth, s. 4I-53.

87 Por.: listy Fryderyka II do Wilhelminy z 3 IV I749 oraz I8 IV I740 , w: „.. solange wir zu zweit sind.”, s. I46 i 147.

88 Wykaz arii skomponowanych przez Fryderyka II znajduje się m.in. w: H. Becker, „Friedrich der Große”, szp. 957-958.

89 „Hasse war nicht imstande, sie zu komponieren. Ich musste sie einem Italiener geben, der nicht allzu viel daraus gemacht hat", zob.: Friedrich der Grosse, t. 2, s. 232.

90 Por.: R. Müller-Lindenberg, Wilhelmine von Bayreuth, s. I43.

9I Por.: list Wilhelminy do Fryderyka II z I6 V 1753, w: Friedrich der Grosse, t. 2, s. 257. 
Więcej o swojej pracy pisarskiej opowiadał Fryderyk ${ }^{92}$. M.in. w kwietniu 1754 r. wysłał Wilhelminie szkic libretta opery Montezuma. Jego treść stanowi historia zdobycia Meksyku przez Hernána Cortesa ${ }^{93}$. Jest to najwybitniejsze dzieło librettowe autorstwa Fryderyka II, które zapisało się na kartach historii muzyki ${ }^{94}$. Zastosował on w nim recytatywy o krótkich rozmiarach oraz wprowadził dwuczęściową cavatinę $\left(\mathrm{a}-\mathrm{a}^{\mathrm{I}}\right) \mathrm{w}$ miejsce stosowanej do tej pory trzyczęściowej formy da capo $\left(\mathrm{aa}^{\mathrm{I}}-\mathrm{b}-\mathrm{aa}\right)^{\mathrm{I}}{ }^{95}$. Mocno podkreślał, że powtarzanie tekstu i muzyki wywołuje efekt znużenia. Pogląd ten podzielała Wilhelmina. W liście z dnia 25 X 1752 r. dzieliła się z bratem wrażeniami po obejrzeniu w Stuttgarcie opery Baldassare Galuppiego pt. Alessandro nell'Indie. Przedstawienie, jak relacjonowała Wilhelmina, trwało za długo (prawie sześć godzin), ponieważ wszystkie arie śpiewano da capo. Praca Fryderyka nad Montezuma zyskała uznanie Wilhelminy, co wynika z jego słów:

Cieszę się, że jesteś zadowolona z mojej opery. Co do kwestii cavatin: widziałem je u Hassego i są one o wiele ładniejsze od arii i są krótkie. Powtórki nie są konieczne, jeżeli śpiewacy wiedzą, jak różnicować muzykę. Zresztą, uważam, że nadużyciem jest czterokrotne powtarzanie tej samej kwestii ${ }^{96}$.

Premiera opery Montezuma, do której muzykę napisał Graun ${ }^{97}$, miała miejsce 6 I 1756 r. i odniosła wielki sukces. W opinii Fryderyka, Graun stworzył dzieło

92 Przy tworzeniu librett Fryderykowi służył radą graf Francesco Algarotti (17I2-64), wybitny intelektualista włoski, który w 1. 1747-53 przebywał w Poczdamie. W roku 1755 opublikował on jedną z najważniejszych rozpraw teoretycznych z zakresu opery, a mianowicie Saggio sopra l'opera, zob. na ten temat literatura muzykologiczna, m.in.: Egon Wellesz, „Algarotti und seine Stellung zur Musik”, Sammelbände der Internationalen Musikgesellschaft I5 (1914) nr 3, s. 427-439; Susanne Oschmann, "Gedankenspiele - Der Opernheld Friedrichs II", w: Opernheld und Opernheldin im I8. Jahrhundert: Aspekte der Librettoforschung, red. Klaus Hortschansky, Hamburg 199I, s. I75-193.

93 Tekst libretta Fryderyk napisał prozą po francusku, a na język włoski przetłumaczył je wierszem Pietro Tagliazucchi.

94 Por. także literatura muzykologiczna, m.in.: Heinz Klüppelholz, „Die Eroberung Mexikos aus preußischer Sicht. Zum Libretto der Oper Montezuma von Friedrich dem Großen”, w: Oper als Text. Romanistische Beiträge zur Libretto-Forschung, red. Albert Gier, Heidelberg 1986, s. 65-94; Peter Schleuning, „Ich habe den Namen gefunden, nämlich Montezuma. Die Berliner Hofopern Coriolano und Montezuma, entworfen von Friedrich II. von Preußen, komponiert von Carl Heinrich Graun”, w: Traditionen - Neuansätze [księga pamiątkowa dla Anny Amalii Abert (1906-96)], red. Kurt Hortschansky, Tutzing 1997, s. 493-518; Arndt Krieger, „Moral und Geschichte - Die Oper "Montezuma» von Friedrich dem Großen", w: Der einsame Held, red. Wilhelm G. Busse, Olaf Templin, Tübingen 2000, s. I25-I45.

95 Por.: list Fryderyka II do Wilhelminy z I6 IV I754, w: Correspondance de Frédéric, s. 242. Zdaniem Heinza Klüppelholza, Montezuma Fryderyka II jest zapowiedzią reformy operowej Christopha Willibalda Glucka, zob.: H. Klüppelholz, „Die Eroberung Mexikos”, s. 77.

96 „Je suis charmé de ce que vous soyez contente de mon opéra. Quant aux cavatines, j’en ai vu de Hasse qui sont infiniment plus jolies que les airs, et qui passent rapidement. Il ne faut des reprises que lorsque les chanteurs savent varier la musique; mais il me semble que, d'ailleurs, il y a de l'abus à répéter quatre fois la même chose", list Fryderyka II do Wilhelminy z 4 V I754, w: Correspondance de Frédéric, s. 243.

97 Fryderyk II napisał jeszcze trzy libretta do oper Grauna: Sulla (1753), I fratelli nemici (1756) i Merope (1756). 
mistrzowskie ${ }^{98}$. Opera ta $\mathrm{w}$ istocie stanowi jedno $\mathrm{z}$ największych sukcesów kompozytora.

Osiem miesięcy po premierze Montezumy wybuchła wojna siedmioletnia. Życie kulturalne zarówno w Prusach, jak i Bayreuth zamarło. I4 X I758 r. zmarła Wilhelmina. Jej śmierć była dla Fryderyka II ciosem bolesnym. Stracił on nie tylko najbliższą mu osobę, ale i partnerów do rozmów o muzyce. Tematów muzycznych nie podjął bowiem w korespondencji z młodszą, bardzo utalentowaną muzycznie siostrą Anną Amalią, z którą w porównaniu z innymi członkami rodziny, łączyły go najserdeczniejsze relacje.

Wojna siedmioletnia zakończyła się w lutym I763 roku. Prusy stały się pierwszą potęgą militarną w Europie. Jednakże powojenna sytuacja finansowa Prus wymusiła na Fryderyku II prowadzenie polityki oszczędnościowej, która dotknęła m.in. dziedzinę kultury. W konsekwencji zainteresowanie Fryderyka II muzyką zaczęło maleć99. Nie podjął ani działalności kompozytorskiej, ani pracy literackiej nad librettami. Wieczorne koncerty kameralne po śmierci Quantza, która nastąpiła I2 VII I773 r., organizowane były coraz rzadziej. W roku I779 z powodu złego stanu zdrowia Fryderyk II zaprzestał gry na flecie. Rzadko też odwiedzał teatr ${ }^{\mathrm{roO}}$. Opera berlińska bowiem, która w roku I764 na nowo podjęła działalność, nie mogła osiągnąć dawnej świetności.

Jak wspomniano na początku artykułu, Fryderyk II był pisarzem, który wypowiadał się na różne tematy. Niestety, wbrew temu, co napisał Ernest Eugene Helm, król pruski nie pozostawił po sobie publikacji z zakresu muzyki ${ }^{\text {IoI }}$. Przywołane bowiem przez Helma Lettres au public (Berlin I753) to publikacja satyryczna, w której Fryderyk II w sposób żartobliwy opisał zabiegi dyplomatyczne swoich czasów. Wspomnieć należy, że Fryderyk II wysoko cenił osiąnnięcia teoretyków niemieckich. W liście do Wilhelminy z dnia I4 XII I739 r. stwierdził, że Niemcy w porównaniu z Włochami są bardziej uczeni i biegli w zakresie teorii muzyki. W istocie Berlin w połowie wieku

98 Por. listy Fryderyka II do Wilhelminy z 2I XI 1754 (w: Correspondance de Frédéric, s. 25I-252) oraz II I 1755 (w: Bagatellen aus Berlin, s. I22). Ponadto Fryderyk II za mistrzowskie dzieła Grauna uważał opery Cleopatra (I742), Cajo Fabrizio (I747) i Ezio (I755).

99 Poglądu tego nie podziela Sabine Henze-Döhring. Jej zdaniem zainteresowanie króla muzyką nie osłabło. Miał on jedynie trudności w skompletowaniu nowego zespołu muzyków. Ponadto w roku I759 zmarł C.H. Graun. Jego miejsce zajął Johann Friedrich Agricola, którego praca nie satysfakcjonowała króla, zob.: S. Henze-Döhring, Markgräfin Wilhelmine, rozdz. I.

Ioo W liście z roku 1770 do landgrafini Karoliny von Hesse-Darmstadt napisał: „Siedem lat tańczyliśmy z Austriakami, Rosjanami i Francuzami, a co za tym idzie, trochę straciliśmy upodobanie do tańca teatralnego lub przynajmniej musimy ograniczyć koszty z nim związane” („[...] pendant sept années consécutives, les Autrichiens, Russes et Français nous ont fait tant danser, que nous avons un peu perdu le goût de la danse théâtrale, ou du moins que nous en bornons la dépense"), zob.: Correspondance de Frédéric avec la landgrave Caroline de Hesse-Darmstadt, w: Oeuvres de Frédéric le Grand, t. 27/2, Berlin I856, s. I42.

Ior Por.: Ernest Eugene Helm, „Frederick II”, w: The New Grove Dictionary of Music and Musicians, red. Stanley Sadie, t. 9, London I980, s. 8II-8I2. 
XVIII stał się centrum muzycznej myśli teoretycznej. Tutaj swoje pisma fachowe opublikowali m.in. Quantz, Friedrich Wilhelm Marpurg, Johann Friedrich Agricola i Johann Philipp Kirnberger ${ }^{\mathrm{IO} 2}$.

Wszechstronne zainteresowania literackie, filozoficzne i artystyczne wyróżniają Fryderyka II i Wilhelminę z grona innych władców ówczesnej Europy. Szczególne zamiłowanie żywili do muzyki. Oboje włożyli doniosły wkład w rozwój kultury muzycznej w swoich krajach - zakładali zespoły, budowali gmachy operowe i zatrudniali wybitnych muzyków. Ponadto pisali libretta operowe, znakomicie grali na różnych instrumentach, a także komponowali. I chociaż w zakresie sztuki kompozycji nie stworzyli dzieł wielkich, to na pewno zasłużyli, by historycy muzyki o nich pamiętali.

\section{BIBLIOGRAFIA}

Bachmann, Erich, red. Markgräfin Wilhelmine von Bayreuth und ihre Welt. München: Bayer. Verwaltung d. Staatl. Schlösser, Gärten u. Seen, I959.

Bauer, Hans-Joachim. „František Benda, ein Musiker aus Berlin zu Gast in Bayreuth”. W: Musik und Theater am Hofe der Bayreuther Markgräfn Wilhelmine, red. Peter Niedermüller, Reinhard Wiesend, 59-66. Mainz: Are Edition, 2002.

Bauer, Hans-Joachim. Rokoko-Oper in Bayreuth. „Argenore” der Markgräfin Wilhelmine. Laaber: Laaber-Verlag, I983.

Becker, Heinz. „Friedrich der Große und die Musik”. W: Preußens großer König, red. Wilhelm Treue, I50-I60. Freiburg in Breisgau: Ploetz, 1986.

Becker, Heinz. „Friedrich II”. W: Die Musik in Geschichte und Gegenwart, red. Friedrich Blume. T. 4, 955. Kassel: Bärenreiter, 1955.

Berger, Günther, Julia Wassermann, red. Bagatellen aus Berlin. Briefe Friedrichs II. an Wilhelmine von Bayreuth. Przekł. Sarah Breitenbach i inni. Berlin, Duncker \& Humblot, 201 .

Berger, Günther, Julia Wassermann, red. Nichts Neues aus Bayreuth: Briefe der Markgräfin Wilhelmine an Friedrich II. und Voltaire. Berlin: Duncker \& Humblot, 2008.

Betzwieser, Thomas, red. Opernkonzeptionen zwischen Berlin und Bayreuth. Das musikalische Theater der Markgräfin Wilhelmine. Würzburg: Königshausen u. Neumann, 2016.

Bischoff, Cordula. „Markgräfin Wilhelmine von Bayreuth (I709-1758)”. W: Deutsche Frauen der Frühen Neuzeit. Dichterinnen, Malerinnen, Mäzeninnen, I53-167. Darmstadt: Wissenschaftliche Buchgesellschaft, 2000.

Bourke, John. „Frederick the Great as Music-Lover and Musicians”. Music and Letters 28, nr I (1947): 63-77.

Briefe Carl Heinrich Grauns. Wyd. Berthold Kitzig. Zeitschrift für Musikwissenschaft 9 (1926/27): 385-405.

IO2 Jednakże w roku I78I zapowiedź opublikowania przez Kirnbergera podręcznika generałbasu pt. Über die Grundsätze des Generalbasses nie wzbudziła entuzjazmu króla. W liście do teoretyka z 25 II I78I r. Fryderyk II wyraził wątpliwość, by dzieło Kirnbergera mogło wnieść coś nowego do nauki generałbasu, ponieważ, jak stwierdził, temat ten opracowany został szczegółowo wiele lat temu, por.: list Fryderyka II do J.Ph. Kirnbergera z 25 II I78I, w: Oeuvres de Frédéric le Grand, t. 27/3, Berlin I856. 
Burney, Charles. Obecny stan muzyki w Niemczech, Niderlandach i Zjednoczonych Prowincjach albo dziennik podróży przez owe kraje, podjęte celem zebrania materiatów dla „Powszechnej historii muzyki”. Przekł. Jakub Chachulski. Warszawa: Muzeum Pałac w Wilanowie, 2018.

Burney, Charles. The Present State of Music in Germany, the Netherlands, and United Provinces: Or, the Journal of a Tour through those Countries, Undertaken to Collect Materials for a General History of Music. T. I-2. London: T. Becket and Co., J. Robson, and G. Robinson, I773, wyd. 2 zmienione 1775 .

Carlyle, Thomas. History of Friedrich II of Prussia, Called Frederick the Great. T. I-8. London: Chapman and Hall, I858-65.

Colton, Judith. The Parnasse François: Titon du Tillet and the Origins of the Monument to Genius. New Haven: Yale University Press, I979.

Correspondance de Frédéric avec la landgrave Caroline de Hesse-Darmstadt. Wyd. Johann David Erdmann Preuss. W: Oeuvres de Frédéric le Grand. T. 27/2. Berlin: Imprimerie royale, I856.

Correspondance de Frédéric avec le comte de Schaumbourg-Lippe. Wyd. Johann David Erdmann Preuss. W: Oeuvres de Frédéric le Grand. T. I6. Berlin: Imprimerie royale, i850.

Correspondance de Frédéric avec sa soeur Wilhelmine, margrave de Baireuth. Wyd. Johann David Erdmann Preuss. W: Oeuvres de Frédéric le Grand. T. 27/I. Berlin: Imprimerie royale, I856.

Correspondance de Frédéric avec Voltaire. Wyd. Johann David Erdmann Preuss. W: Oeuvres de Frédéric le Grand. T. 22. Berlin: Imprimerie royale, I853.

Dannhauser, Monique. Aus Frankreich nach Deutschland. Die französischen Hugenotten und ihr Sproß Jacques-Egide Duhan de Jandun, Präzeptor des Preußenkönigs Friedrich II. Egelsbach: Hänsel-Hohenhausen, I999.

Dubowy, Norbert, Corinna Harr, Alina Żórawska-Witkowska, red. Italian Opera in Central Europe I6I4-I780. T. 3. Berlin: Berliner Wissenschafts-Verlag, 2007.

Duffy, Christopher. Frederick the Great. A Military Life. London: Routledge, 1985.

Duffy, Christopher. Fryderyk Wielki. Biografia wojskowa. Przekł. Miłosz Młynarz. Oświęcim: Napoleon V, 2017.

Dümling, Albrecht. „Friedrich II, sein Lehrer Quantz und der deutsche Geschmack in der Musik". Zeitschrift für Religions- und Geistesgeschichte 56, $\mathrm{nr} 2$ (2004): I24-I35.

Friedrich der Grosse. De la littérature allemande. W: Oeuvres de Frédéric le Grand, red. Johann David Erdmann Preuss. T. 7. Berlin: Imprimerie royale, I847.

Friedrich der Grosse. Discours de l'utilité des sciences et des arts dans un état. W: Oeuvres de Frédéric le Grand, red. Johann David Erdmann Preuss. T. 9. Berlin, Imprimerie royale, I848.

Friedrich der Grosse. Épitre à mon esprit. W: Oeuvres de Frédéric le Grand, red. Johann David Erdmann Preuss. T. Io. Berlin: Imprimerie royale, I849.

Friedrich der Grosse. L'Antimachiavel. W: Oeuvres de Frédéric le Grand, red. Johann David Erdmann Preuss. T. I. Berlin: Imprimerie royale, I846.

Friedrich Wilhelm Prinz von Preußen, Kirsten Heckmann-Janz, Sibylle Kretschmer, red. „... solange wir zu zweit sind.” Friedrich der Große und Wilhelmine Markgräfin von Bayreuth in Briefen. Przekł. Friedrich von Oppeln-Bronikowski. München: Langen -Müller, 2003.

Gaxotte, Pierre. Frédéric II. Paris: Librairie Arthème Fayard, 1938.

Gooch, George Peabody. Frederick the Great, the Ruler, the Writer, the Man. New York: Alfred A. Knopf, 1947.

Grosch, Hartmut. „Christoph Schaffrath. Komponist - Cembalist - Lehrmeister”. W: Die Rheinsberger Hofkapelle von Friedrich II, red. Ulrike Liedtke, 203-238. Rheinsberg: Veröffentlichung der Musikakademie Rheinsberg, I995; wyd. 2 Leipzig: Hofmeister, 2005. 
Helm, Ernest Eugene. „Frederick II”. W: The New Grove Dictionary of Music and Musicians, red. Stanley Sadie. T. 9, 8II-8I2. London: Oxford University Press, I980.

Helm, Ernest Eugene. Music at the Court of Frederick the Great. Norman: University of Oklahoma Press, I960.

Henze-Döhring, Sabine. Friedrich der Große. Musiker und Monarch. München: C.H. Beck, 2012.

Henze-Döhring, Sabine. Markgräfin Wilhelmine und die Bayreuther Hofmusik. Bamberg: Heinrichs-Verlag GmbH, 2009.

Henzel, Christoph. „Zu den Aufführungen der großen Oper Friedrichs II. von Preußen 1740-1756". Jahrbuch des Staatlichen Instituts für Musikforschung Preußischer Kulturbesitz 8 (1997): 47-53.

Hirschmann, Wolfgang. „Italienische Opernpflege am Bayreuther Hof. Der Sänger Giacomo Zaghini und die Oper Argenore der Markgräfin Wilhelmine”. W: Italienische Musiker und Musikpflege an deutschen Höfen der Barockzeit, red. Friedhelm Brusniak, II7-I53. Köln: Studiopunkt Verlag, I995.

Hirschmann, Wolfgang. „Von der Zuständigkeit der Dilettantin: Wilhelmines Argenore (1740) und die Musikgeschichte des I8. Jahrhunderts". W: Opernkonzeptionen zwischen Berlin und Bayreuth. Das musikalische Theater der Markgräfin Wilhelmine, red. Thomas Beztzwieser, 4I-53. Würzburg: Königshausen \& Neumann, 2016.

Horn, Georg. Voltaire und die Markgräfin von Baireuth. Berlin: Verl. der Königlichen Geheimen Ober-Hofbuchdr, I865.

Kapell Loewy, Andrea. „Frederick the Great. Flutist and Composer”. College Music Symposium 30, $\mathrm{nr} 2$ (1990): II7-I25.

Klüppelholz, Heinz. „Die Eroberung Mexikos aus preußischer Sicht. Zum Libretto der Oper Montezuma von Friedrich dem Großen”. W: Oper als Text. Romanistische Beiträge zur Libretto-Forschung, red. Albert Gier, 65-94. Heidelberg: Universitätsverlag Winter $\mathrm{GmbH}$, i986.

Konopczyński, Władysław. Fryderyk Wielki a Polska. Poznań: Instytut Zachodni, 1947.

Krieger, Arndt. „Moral und Geschichte - Die Oper «Montezuma» von Friedrich dem Grossen". W: Der einsame Held, red. Wilhelm G. Busse, Olaf Templin, I25-I45. Tübingen: Francke Verlag, 2000.

Kucharczyk, Grzegorz. Hohenzollernowie. Poznań: Wydawnictwo Poznańskie, 2016.

Kunisch, Johannes. Friedrich der Grosse. Der König und seine Zeit. München: C.H. Beck, 2004.

Liedtke, Ulrike. „Johann Joachim Quantz und Friedrich II. Eine musikalische Verbindung". W: Die Rheinsberger Hofkapelle von Friedrich II. Musiker auf dem Weg zum Berliner „Capell-Bedienten”, red. Ulrike Liedtke, 5I-86. Rheinsberg: Musikakademie Rheinsberg, 2005 .

Margrabina von Bayreuth Wilhelmina Fryderyka Zofia. Pamiętniki. Przekł. Irena Wachlowska. Warszawa: Czytelnik, I973.

Mayer-Reinach, Albert. „Carl Heinrich Graun als Opernkomponist”. Sammelbände der Internationalen Musikgesellschaft I, nr 3 (1900): 446-529.

Müller, Georg. Friedrich der Grosse, seine Flöten und sein Flötenspiel. Berlin: A. Parryhysius, 1932.

Müller-Lindenberg, Ruth. Wilhelmine von Bayreuth. Die Hofoper als Bühne des Lebens. Köln: Böhlau, 2005.

Nahajowski, Marek. Sonaty fletowe Johanna Joachima Quantza. Między teoria a praktyka. Łódź: Akademia Muzyczna w Łodzi, 2013. 
Niedermüller, Peter, Reinhard Wiesend, red. Musik und Theater am Hofe der Bayreuther Markgräfin Wilhelmine. Mainz: Are Verlag, 2002.

Oleskiewicz, Mary. "The Court of Brandenburg-Prussia”. W: Music at German Courts, I7I5-I760. Changing Artistic Priorities, red. Samantha Owens, Barbara M. Reul, Janice B. Stockigt, 79-I30. Woodbridge: Boydell \& Brewer, 2011.

Oschmann, Susanne. „Gedankenspiele - der Opernheld Friedrichs II”. W: Opernheld und Opernheldin im I8. Jahrhundert: Aspekte der Librettoforschung, red. Klaus Hortschansky, I75-193. Hamburg: K.D. Wagner, I991.

Oster, Uwe. Wilhelmine von Bayreuth. Das Leben der Schwester Friedrichs des Großen. München: Piper, 2005 .

Quantz, Johann Joachim. Lebenslauf. W: Friedrich Wilhelm Marpurg. Historisch-Kritische Beyträge zur Aufnahme der Musik. T. I, 197-250. Berlin: Gottlieb August Lange, 1754-55.

Reichardt, Johann Friedrich. Musikalisches Kunstmagazin. T. 2. Berlin: Verlag des Verfassers, I79I.

Reilly, Edward R. „Quantz, Johann Joachim”. W: The New Grove Dictionary of Music and Musicians, red. Stanley Sadie. T. I5, 495-497. London: Oxford University Press, 2001.

Sagave, Pierre-Paul. Berlin und Frankreich I685-185I. Berlin: Haude \& Spener, I980.

Salmonowicz, Stanisław. Fryderyk II. Wrocław: Zakład Narodowy im. Ossolińskich, 1985.

Schenk, Erich. Giuseppe Antonio Paganelli. Sein Leben und seine Werke, nebst Beiträgen zur Musikgeschichte Bayreuths. Salzburg: Waldheim-Eberle, 1928.

Schleuning, Peter. „Ich habe den Namen gefunden, nämlich Montezuma. Die Berliner Hofopern Coriolano und Montezuma, entworfen von Friedrich II. von Preußen, komponiert von Carl Heinrich Graun”. W: Traditionen - Neuansätze, red. Kurt Hortschansky, 493-5I8. Tutzing: Schneider, 1997.

Sösemann, Bernd, Bernd Vogt-Spira, red. Friedrich der Grosse in Europa - Geschichte einer wechselvollen Beziehung. Stuttgart: Franz Steiner Verlag, 2012.

Sulzer, Johann Georg. Allgemeine Theorie der schönen Künste. T. 2. Leipzig: M.G. Weidemann, 1774 .

Thiel, Heinrich. Wilhelmine von Bayreuth. Die Lieblingsschwester Friedrichs des Großen. München: Nymphenburger, 1967.

Thouret, Georg. Friedrich der Große als Musikfreund und Musiker. Leipzig: Breitkopf und Härtel, I898.

Van der Hoven, Lena, Melanie Wald-Fuhrmann. La Musique c'est moi. Friedrichs II. klingender Weg zur historischen Größe. Berlin: Vergangenheitsverlag, 2013.

Van der Hoven, Lena. Musikalische Repräsentationspolitik in Preußen (I688-1797). Hofmusik als Inszenierungsinstrument von Herrschaft. Kassel: Bärenreiter, 2015.

Vill, Susanne. „Argenore inszenieren. Die Oper von Wilhelmine von Bayreuth im Markgrafentheater Erlangen". W: Théâtre, Musique et Arts dans les Cours Européennes de la Renaissance et du Baroque, red. Kazimierz Sabik, 517-536. Varsovie: Editions de l'Université de Varsovie, Faculté des lettres modernes, 1997.

Volz, Gustav Berthold, red. Friedrich der Grosse und Wilhelmine von Baireuth. Przekł. niem. Friedrich von Oppeln-Bronikowski. T. I-2. Leipzig: Köhler, 1924, I926.

Wellesz, Egon. „Algarotti und seine Stellung zur Musik”. Sammelbände der Internationalen Musikgesellschaft I5, nr 3 (1914): 427-439.

Wilhelmine von Bayreuth. Eine preussische Königstochter. Glanz und Elend am Hofe des Soldatenkönigs in den Memoiren der Markgräfin Wilhelmine von Bayreuth. Wyd. Ingeborg Weber-Kellermann, przekł. Annette Kolb. Frankfurt am Main: Insel, ${ }^{12} 2019$. 
Woyke, Saskia Maria. „Virtuosinnen und ein Virtuose in Bayreuth - Anmerkungen zu den von der Markgräfin Wilhelmine engagierten Sängerinnen und Sängern”. W: Opernkonzeptionen zwischen Berlin und Bayreuth. Das musikalische Theater der Markgräfin Wilhelmine, red. Thomas Betzwieser, 55-70. Würzburg: Königshausen u. Neumann, 2016.

Źórawska-Witkowska, Alina. Muzyka na polskim dworze Augusta III. Cz. I. Lublin: Polihymnia, 2012.

\section{MUSICAL TOPICS IN THE CORRESPONDENCE BETWEEN FREDERICK II OF PRUSSIA} AND HIS SISTER WILHELMINE, MARGRAVINE VON BRANDENBURG-BAYREUTH

Frederick II the Great (I7I2-86) went down in history as an outstanding political and military strategist. Under his rule, Prussia became one of Europe's greatest powers. He was also a lover of science and the arts, including music. He shared his musical passions with his elder sister Wilhelmine (1709-58). Both learned the harpsichord and the lute, and Frederick also played the flute. They composed music and wrote operatic libretti. After her wedding, Wilhelmine left for Bayreuth (1732), where she engaged in organising cultural life.

Frederick II and Wilhelmine stand out among other European rulers of that period owing to their versatile artistic and scientific interests. They were both patrons of the arts who significantly contributed to musical culture in their respective states. They founded music ensembles, built opera houses and employed eminent musicians. Those who found employment in Berlin include Johann Joachim Quantz, Carl Heinrich Graun, Franz Benda, Carl Philipp Emanuel Bach, Felice Salimbeni and Giovanna Astrua; in Bayreuth - Adam Falckenhagen, Johann Pfeiffer, Giuseppe Antonio Paganelli and Giacomo Zaghini.

Frederick II and Wilhelmine kept up a lively correspondence, which testifies to their shared interest in philosophy, literature, theatre and music. They discussed musical subjects in their letters, exchanged opinions on individual compositions and artists, and sent each other scores (of their own music, as well as pieces by other composers, such as Quantz, Graun and Benda, as well as Johann Adolf Hasse and Christoph Schaffrath). Their musical interests focused on chamber music and opera.

Translated by Tomasz Zymer

Słowa kluczowe / key words: Fryderyk II Wielki / Frederick II the Great, Wilhelmina von Bayreuth / Wilhelmine von Bayreuth, XVIII wiek / I8th century, muzyka kameralna / chamber music, opera

Dr Katarzyna Korpanty ukończyła studia w zakresie germanistyki i muzykologii na Uniwersytecie Jagiellońskim. Pracuje jako adiunkt w Zakładzie Muzykologii Instytutu Sztuki PAN. Jej zainteresowania badawcze koncentrują się na historii i teorii muzyki w wiekach XV-XVIII, ze szczególnym uwzględnieniem zagadnienia relacji słowo-dźwięk oraz protestanckiej kultury muzycznej. W 2019 r. opublikowała monografię Niemiecka nauka kompozycji $w$ XVII i na początku wieku XVIII.

katarzyna.korpanty@ispan.pl 
